Original Article

\title{
COMPARISON IMMUNOHISTOCHEMISTRY EXPRESSION OF DESIDUAL NATURAL KILLER (dNK) IN SEVERE PREECLAMPSIAAND NORMAL PREGNANCY
}

\author{
MUARA P. LUBIS1 \\ ${ }^{1}$ Fetomaternal Division, Department of Obstetrics and Gynecology, Faculty of Medicine, Universitas Sumatera Utara \\ Email: mploebis@yahoo.com
}

Received: 25 Jan 2020, Revised and Accepted: 18 Mar 2020

\begin{abstract}
Objective: Preeclampsia characterized systematically by extensive vascular endothelial dysfunction and microangiopathy on mother, dNK is very important for the success of placentation. They are the key mediator of maternal immune system interactions with fetal cells. dNK cells are also involved in the modulation of EVT and the remodeling of spiral arteries.

Methods: Analytic research with cross-sectional study, with samples of pregnant women who suffer from severe PE and aterm pregnancy which came to H. Adam Malik Hospital and Networking Hospital, November 2015-April 2016. The samples are 46 women, who met the inclusion criteria.

Results: Immunohistochemistry examination $\mathrm{dNK}$ cell in the severe PE case group and control group, statistically found p<0,05. $\mathrm{dNK}$ placenta expression in the severe preeclampsia case group gives an overview of expression with a mean of $2.55 \pm 2.31$, while the control group of normal pregnancy had higher mean is $8.66 \pm 3.16$.
\end{abstract}

Conclusion: The examination of immunohistochemistry of dNK cells showed there is a significant difference in the expression of Immunohistochemistry dNK cells between severe PE case group and non severe PE.

Keywords: Severe preeclampsia, Normal pregnancy, Expression of dNK cell

(C) 2020 The Authors. Published by Innovare Academic Sciences Pvt Ltd. This is an open access article under the CC BY license (http://creativecommons.org/licenses/by/4.0/] DOI: http://dx.doi.org/10.22159/ijcpr.2020v12i3.38306. Journal homepage: https://innovareacademics.in/journals/index.php/ijcpr

\section{INTRODUCTION}

Preeclampsia is systemically characterized by widespread vascular endothelial dysfunction and microangiopathy in the mother, but not in the fetus. At present it is believed that preeclampsia starts with abnormalities in the development of blood vessels in the placenta that cause an effect on the maternal endothelium $[1,4,5]$.

Knowledge of cellular and molecular processes of human trophoblast invasion is based on in vitro research and animal models; there is evidence that decidual natural killer $(\mathrm{dNK})$ cells are very important in successful placentation. They are key mediators of the interaction of the mother's immune system with fetal cells. DNK cells are also involved in modulation of invasion of extravillous trophoblasts (EVT) and remodeling of the maternal spiral arteries. They express various surface receptors and signaling molecules, including cytokines, chemokines, and growth factors, and their function in modulating EVT migration, invasion, and change from epithelial phenotype to endothelial are beginning to be revealed [6].

\section{MATERIALS AND METHODS}

This study is a comparative analytic study with a cross-sectional study design conducted at General Hospital. H. Adam Malik Medan,
RSUD dr. Pirngadi Medan, and Faculty of Medicine, University of North Sumatra Networking Hospital from November 2015 to April 2016. The sample of the study was 23 pregnant women suffering from PEB and normal pregnant women with a term gestational age for each group who met the inclusion criteria, namely pregnant women aged 18-35 y, singleton pregnancy, severe preeclampsia, term and exclusion criteria ie damaged placenta samples; who came for pregnancy control to General Hospital H. Adam Malik Medan, RSUD dr. Pirngadi Medan, Faculty of Medicine, University of North Sumatra Networking Hospital.

\section{Work arrangement}

Taken in the middle of the maternal side opposite the insertion site of the umbilical cord on the fetal surface with a size of $1.5 \times 1.5 \times 1$ $\mathrm{cm}$. Then fixed in $10 \%$ formalin liquid with a time limit of $24-48 \mathrm{~h}$, dried with ethanol and cleaned with xylol and implanted in a paraffin block. Paraffin is cut $7 \mu \mathrm{m}$. Stained with Hematoxyclin and Eosin ( $\mathrm{H}$ and $\mathrm{E}$ ). Immunohistochemically stained for CD56 to detect dNK cells using CD56 anti antibodies. The preparations were interpreted by two Anatomical Pathologists. The results of the preparation of these preparations are carried out statistical analysis with Statistical Product and Service Solutions (SPSS) Ver. 18

\section{RESULTS}

Characteristics of research subjects

Table 1: Distribution characteristics of research subjects in severe preeclampsia case group and normal pregnancy group

\begin{tabular}{|c|c|c|c|c|c|c|c|}
\hline \multirow[t]{2}{*}{ Characteristics } & \multicolumn{4}{|l|}{ Research subjects } & \multirow[t]{2}{*}{ Total } & \multirow[t]{2}{*}{$\%$} & \multirow[t]{2}{*}{ p value } \\
\hline & Severe preeclampsia & $\%$ & Normal pregnancy & $\%$ & & & \\
\hline \multicolumn{8}{|l|}{ Age (years old) } \\
\hline $15-25$ & 3 & 13 & 8 & 34,8 & 11 & 23,9 & $0,062^{* *}$ \\
\hline $26-35$ & 16 & 69,6 & 15 & 65,2 & 31 & 67,4 & \\
\hline$>35$ & 4 & 17,4 & 0 & 0 & 4 & 8,7 & \\
\hline \multicolumn{8}{|l|}{ Parity } \\
\hline Primigravida & 7 & 30,4 & 5 & 21,7 & 12 & 26,1 & $0,611^{*}$ \\
\hline
\end{tabular}




\begin{tabular}{|c|c|c|c|c|c|c|c|}
\hline Secundigravida & 6 & 26,1 & 9 & 39,1 & 15 & 32,6 & \multirow{6}{*}{$0,058^{* * *}$} \\
\hline Multigravida & 10 & 43,5 & 9 & 39,1 & 19 & 41,3 & \\
\hline \multicolumn{7}{|l|}{ Birth Weigth } & \\
\hline Low Birth Weight & 5 & 21,7 & 0 & 0 & 5 & 10,9 & \\
\hline $\begin{array}{l}\text { Normal } \\
\text { APGAR Score }\end{array}$ & 18 & 78,3 & 23 & 100 & 41 & 89,1 & \\
\hline Good & 23 & 100 & 23 & 100 & 46 & 100 & \\
\hline \multicolumn{8}{|l|}{ PROTEINURIA } \\
\hline$(+2)$ & 9 & 39,1 & 0 & 0 & 9 & 19,6 & \\
\hline$(+3)$ & 11 & 47,8 & 0 & 0 & 11 & 23,9 & \\
\hline$(+4)$ & 3 & 13,0 & 0 & 0 & 3 & 6,5 & $0,001^{* *}$ \\
\hline Negative & 0 & 0 & 23 & 100 & 23 & 50 & \\
\hline Total & 23 & 100 & 23 & 100 & 46 & 100 & \\
\hline
\end{tabular}

${ }^{*}$ Chi-square test ${ }^{* *}$ Fisher Exact test ${ }^{* * *}$ Continuity Correction

Table 2: Differences in dNK cell expression between severe preeclampsia case group and normal pregnancy group

\begin{tabular}{lllll}
\hline Research subjects & N & \multicolumn{2}{l}{ CD56 expressions } & p value \\
\cline { 3 - 4 } & & Mean & Std. deviasi & 0,031 \\
\hline Severe Preeclampsia & 23 & 2,55 & 2,31 & 3,16 \\
Normal Pregnancy & 23 & 8,66 & 23 & \\
\hline
\end{tabular}

Table 3: Differences in dNK cell expression between severe preeclampsia case group and normal pregnancy group based on Normal birth weigth and low birth weight (LBW)

\begin{tabular}{|c|c|c|c|c|}
\hline \multirow[t]{2}{*}{ Birth weight } & \multirow[t]{2}{*}{$\mathbf{N}$} & \multicolumn{2}{|c|}{ CD56 expressions } & \multirow[t]{2}{*}{ p value } \\
\hline & & Mean & Std. deviasi & \\
\hline Normal & 41 & 6,9451 & 5,20322 & 0,003 \\
\hline LBW & 5 & 2,4000 & 2,00468 & \\
\hline
\end{tabular}

Table 4: Differences in expression of dNK cells based on proteinuria

\begin{tabular}{llll}
\hline Research subjects & $\mathbf{N}$ & \multicolumn{2}{l}{ CD56 expressions } \\
\cline { 3 - 4 } & & Mean & Std. deviasi \\
\hline Proteinuria & & & \\
Negative & 23 & 9,6957 & 4,24997 \\
$(+2)$ & 9 & 3,8889 & 4,90075 \\
$(+3)$ & 11 & 2,7045 & 2,93645 \\
$(+4)$ & 3 & 3,0000 & 3,46410 \\
\hline
\end{tabular}

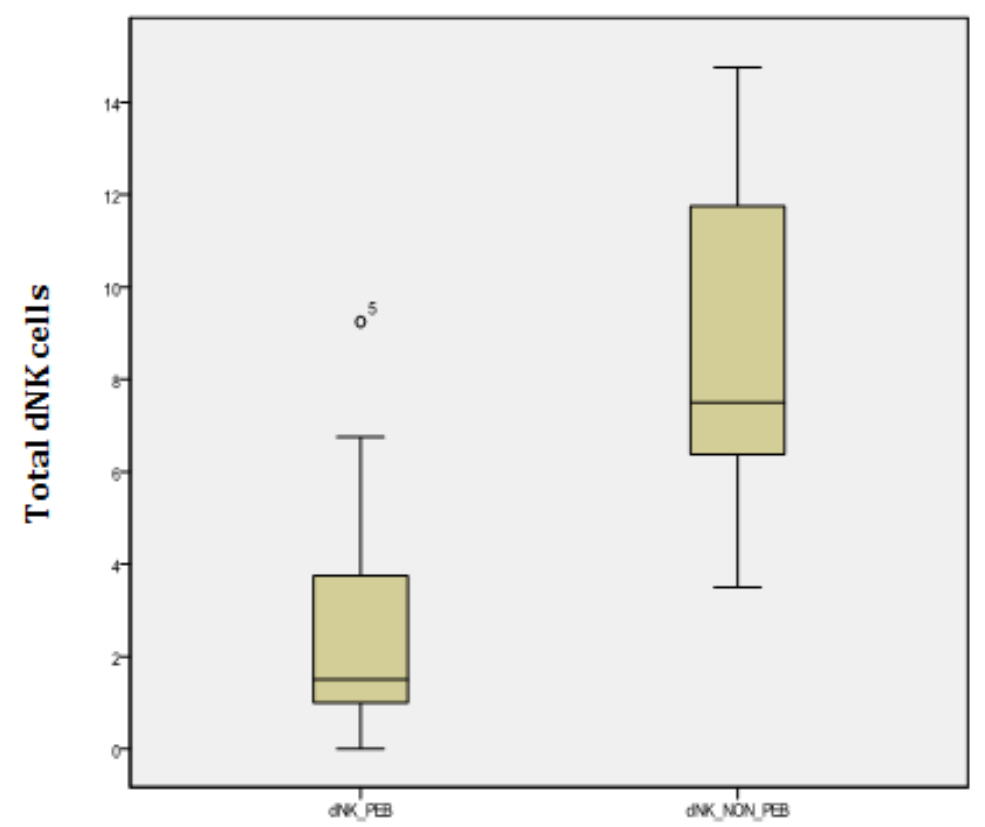

Fig. 1: Boxplot showing mean number of dNK cells in placenta with severe preeclampsia and normal pregnancy 


\section{DISCUSSION}

\section{Immunohistochemistry examination results}

The results of this study found that the results of immunehistochemistry dNK cells examination in the severe preeclampsia case group generally gave a description of expression with a mean of $2.55 \pm 2.31$ while in the normal pregnancy control group had a higher mean with $8.66 \pm 3.16$. Statistically obtained $p$ value $<0.05$ which indicates there is a significant difference in the expression of immunohistochemistry dNK cells between severe preeclampsia case group and normal pregnancy group.

In another study by Charles et al. stated that dNK cells in women with preeclampsia were significantly less than controls (normotension). Closely related between $\mathrm{dNK}$ cells and blood vessels, dNK cells trigger angiongenic factors on the effects of IFN- $\gamma$ to facilitate remodeling of normal blood vessels $[57,70,71]$. Rieger et al. in their study found that there was a significant relationship between CD56+/CD16+dNK cell counts that increased in the normal pregnancy group than in severe preeclampsia group $(7.3 \%$ vs $5.3 \%$, $\mathrm{p}<0.02)$ [58]. Williams et al. Observed that CD56+NK cells ( $\mathrm{p}=0.01)$ decreased in placental bearing biopsies in PE pregnancy women compared to normal third trimester pregnancy [59]

\section{CONCLUSION}

Immunohistochemistry examination of $\mathrm{dNK}$ cell in severe preeclampsia case group generally gave a picture of expression with a mean of $2.55 \pm 2.31$ while in the normal pregnancy control group had a higher mean with $8.66 \pm 3.16$. Which showed significant differences in the expression of immunohistochemistry dNK cell between severe preeclampsia case group and normal pregnancy group.

\section{ACKNOWLEDGEMENT}

On this special joyful occasion, let me express my deepest gratitude to: Dr. dr. Makmur Sitepu, M. Ked (OG), SpOG. K, Prof. dr. Daulat Sibuea, SpOG. K, dr. Makmur Sitepu, M. Ked (OG), SpOG. K, dr. Jessy Chrestella, M. Ked (PA), SpPA, dr. Surya Darma who has helped a lot in this research. Beloved wife, Dr. Fithria Aldy, M. Ed (Oph), Sp. M, and our three children Gandisyah Khalisa Mahira Lubis, Gandira Alisha Hanifa Lubis, and M. Chairuddin Martua Lubis. May Allah Subhanahu wa ta'ala bestow His mercy and guidance on us all. In addition, researchers are aware of the need for further research so that in the future it can become a reference basis for immunological therapy in severe preeclampsia

\section{FUNDING}

Nil

\section{AUTHORS CONTRIBUTIONS}

All the authors have contributed equally.

\section{CONFLICT OF INTERESTS}

There is no conflict of interest in this research.

\section{REFERENCES}

1. Karumanchi SA, Maynard SE, Stillman IE, Epstein FH, Sukhatme VP. Preeklampsia: a renal perspective. Kidney Int 2005;67:2101-13.
2. Sibai B, Dekker G, Kupferminc M. Pre-eclampsia. Lancet 2005;365:785-99.

3. Duley L. The global impact of pre-eclampsia and eclampsia. Semin Perinatol 2009;33:130-7.

4. Fisher SJ. The placental problem: linking abnormal cytotrophoblast differentiation to the maternal symptoms of preeklampsia. Reprod Biol Endocrinol 2004;2:53.

5. Kopcow HD, Karumanchi SA. Angiogenic factors and natural killer (NK) cells in the pathogenesis of preeclampsia. J Reprod Immunol 2007;76:23-9.

6. Eastabrook G. The role of decidual natural killer cells in normal placentation and in the pathogenesis of preeklampsia. Obstet Gynaecol Can 2008;30:467-76

7. Kumar V, Medhi B. Emerging role of uterine natural killer cells in establishing pregnancy. Iran J Immunol 2008;5:71-81.

8. Kopcow HD, Karumanchi SA. Angiogenic and natural killer (NK) cells in the pathogenesis of preeclampsia. J Reprod Immunol 2007;76:23-9.

9. Milne F, Redman C, Walker J. The pre-eclampsia community guideline (PRECOG): how to screen for and detect onset of preeklampsia in the community. Br Med J 2005;330:576-80.

10. Steegers EAP. Pre-eclampsia. Lancet 2010;376:631-44.

11. Uzan Jennifer. Marie Carbonnel. Olivier Piconne. Pre-eclampsia: pathophysiology, diagnosis, and management. Vasc Health Risk Manage 2011;7:467-74.

12. Ng EH, Chan CC, Tang OS, Yeung WS, Ho PC. The role ofendometrial and subendometrial vaskular ity measured bythree-dimensional power doppler ultrasound in the prediction of pregnancy during frozen-thawed embryo transfer cycles. Hum Reprod 2006;21:1612-7.

13. Burton GJ, Jauniaux E. Placental oxidative stress: from miscarriage to preeklampsia. J Soc Gynecol Investig 2004;11:342-52.

14. Jauniaux E, Watson AL, Hempstock J, Bao YP, Skepper JN Burton GJ. Onset of maternal arterial blood flow and placental oxidative stress. A possible faktor in human early pregnancy failure. Am J Pathol 2000;157:2111-22.

15. Plasencia W, Maiz N, Bonino S, Kaihura C, Nicolaides $\mathrm{KH}$. Uterine artery Doppler at $11+0$ to $13+6 \mathrm{w}$ in the prediction of pre-eclampsia. Ultrasound Obstet Gynecol 2007;30:742-9.

16. Burton GJ. Oxygen, the janus gas; its eff ects on human placental development and function. J Anat 2009;215:27-35.

17. Burton GJ, Yung HW, Cindrova Davies T, Charnock Jones DS, Placental endoplasmic reticulum stress and oxidative stress in the pathophysiology of unexplained intrauterine growth restriction and early onset preeklampsia. Placenta 2009;30(Suppl A):43-8.

18. Jauniaux E, Poston L, Burton GJ. Placental-related diseases of pregnancy: Involvement of oxidative stress and implications in human evolution. Hum Reprod Update 2006;12:747-55.

19. Brosens JJ, Parker MG, McIndoe A, Pijnenborg R, Brosens IA. A role for menstruation in preconditioning the uterus for successful pregnancy. Am J Obstet Gynecol 2009;200:615.

20. Huppertz B. Placental origins of preeklampsia: challenging the current hypothesis. Hypertension 2008;51:970-5.

21. Myers J, Mires G, Macleod M, Baker P. In preeklampsia, the circulating faktors capable of altering in vitro endothelia function precede clinical disease. Hypertension 2005;45:258-63.

22. Irani RA, Xia Y. The functional role of the renin-angiotensin system in pregnancy and preeklampsia. Placenta 2008;29:763-71 